\title{
DRY GRASSLAND VEGETATION ON GALIČICA MOUNTAIN (SW MACEDONIA)
}

\author{
Renata Ćušterevska \\ Institute of Biology, Faculty of Natural Sciences and Mathematics, Ss. Cyril and Methodius University, \\ Skopje, Republic of Macedonia \\ renatapmf@yahoo.com
}

\begin{abstract}
This paper presents the dry grassland vegetation (Festuco-Brometea) on the Galičica Mountain. The research underlying this study was carried out in the period of 2009-2010 at several localities, on carbonate substrate from Ohrid and Prespa sides. Registered community of this type is subordinate to xerophilous vegetation of the Festuco-Brometea the order Astragalo-Potentilletalia Micevski [1] and alliance Saturejo-Thymion Micevski [2]. From the floristic composition and the detailed phytocoenological analysis of the investigated vegetation it was concluded that it is represented by ass. Siderito montanae-Trifolietum dalmaticae ass. nova subass. erodietosum guicciardii subass. nova.
\end{abstract}

Key words: vegetation, dry grasslands, Galičica

\section{INTRODUCTION}

This study deals with the syntaxonomic position and the ecological characteristics of the dry grasslands on the territory of the National Park Galičica. Dry grasslands have an important role in sustaining the biodiversity of the National Park Galičica by harboring many rare and endangered plant species (Erodium guiciardii, [3], Minuartia glomerata subsp. macedonica, Centaurea grisebachii, Verbascum longifolium subsp. pannosum, etc.) In the lowland belt to 1000 (1200) above sea level, in the belt of oak forests (Fraxino orniQuercetum petraeae, Ostryo carpinifoliaeQuercetum cerris and Fraxino orni-Quercetum cerris), and some in the lower belt of beech forest, on the altitude of 700-1200 m [4], [5], with their degradation (uprooting, burning or prolonged use of forests for firewood or other uses), these habitats are gradually transformed into dry grasslands which are secondary phytocenoses maintained through grazing and other anthropogenic activities. The communities of this vegetation type from the central and southern parts of the Balkan Peninsula be- long to the class Festuco-Brometea, order Astragalo-Potentilletalia Micevski [1] Matevski [6].

Festuco-Brometea class is represented by thermophilic communities that develop mainly in the belt of hilly pastures, rocks and pastures with deeper soil layer. The communities of this class are prevalent in the area of Atlantic, Central Europe and in the sub-Mediterranean region [7]. Xerophilous vegetation of the class Festuco-Brometea covers large areas of the Balkan Peninsula from the sub-Mediterranean zone to subalpine belt, at an altitude between 200 and $1550-1600 \mathrm{~m}$. The communities in this class find optimal conditions for their development on warmer habitats, secondary habitats that represent the final stages of degradation of forest vegetation communities of the following orders: Quercetalia pubescenti-petraeae Klika [8] and Fagetalia sylvaticae [9]. In the composition of the communities that have developed in the southern part of the Balkan Peninsula the species of Balkan, Illyrian, south Balkan, southeast-European floral elements, as well as local endemic species, are of particular significance. 
For the Balkan Peninsula, two regional orders of the Festuco-Brometea have traditionally been used: Festucetalia valesiacae (pontic), Astragalo-Potentilletalia (central Balkans) and Scorzonero villosae-Chrysopogonetalia grylli (Illyrian region) [7].

The dry grasslands on the territory of Macedonia, according to Micevski $[1,2,10]$, are subordinated to the order Astragalo-Potentilletalia and were divided into three alliances - Trifolion cherleri Micevski [11], Saturejo-Thymion Micevski [2] and Armerio-Potentillion Micevski [10].

At that time Micevski could not have an overview of the vegetation of Europe, and integrated all dry grasslands into one order that is nowadays divided into several classes. According to the latest concept of Mucina et al. [12], the alliance Trifolion cherleri, which includes the communities of the belt of hilly pastures that develop on silicate surfaces in the altitude belt of $100-900 \mathrm{~m}$, is transferred to the class Helianthemetea guttati, while the communities of the alliance Armerio-Potentillion, which develop also on silicate substrate on the territory of Macedonia and inhabit the area between $1000-1400 \mathrm{~m}$, are transferred to the class Stipo giganteae-Agrostietea castellanae Rivas-Mart. et al. [13], Romeo di Petro et al. [14]. In accordance with the latest sintaxonomic solutions, Matevski et al. [12] the order Astragalo-Potentilletalia is associated only with the communities of the belt of hilly pastures on the territory of Macedonia and northern Greece, which develop on carbonate substrate and belong to the alliance Saturejo-Thymion.

The order Astragalo-Potentilletalia, which is especially important for the southern Balkans or eastern sub-Mediterranean, unites communities from the hilly pastures that develop under the impact of the Mediterranean or modified Mediterranean climate, on carbonate geological surface [1]. As a result of the ecological conditions, the dry calcareous grassland communities on the territory of the Republic of Macedonia can be divided into two subgroups: steppe that develop on a flat surfaces with fragmented bedrock, and rocky grasslands.

This order, according to the concept of Matevski et al. [6], is represented by the alliance Saturejo-Thymion Micevski [2]. It should be noted that the alliance Saturejo-Thymion and the order Astragalo - Potentilletalia, which were described by Micevski [1], were validated a year later because according to the "International code of phytosociological nomenclature" [15] if a union is to be validly described, it should also include at least one validly described association. Considering that, the first association described validly from the alliance Saturejo-Thymion was ass. BrachypodioOnobrychetum pindicolae [2], therefore, 1971 is considered as the year when the alliance and the order were validly described.

Within the order Astragalo-Potentiletallia, from the Republics of Serbia and Kosovo the alliances Scabioso-Trifolion dalmatici [16] and Koelerio-Festucion dalmaticae [17] were described, while from the territory of Greece, the alliance Alyssion muralis [18] was described, but in the light of new research, according to the concept of Mucina et al, [12], they have been transferred to other orders within the class, or within other classes.

The study area was previously an object of floristic and vegetational investigations [19-26]. The present study was thus aimed at gaining a more complete understanding of the vegetational characteristics of the dry grasslands of the investigated area, as a basis for synphytosociological studies. All this indicated the necessity of taking additional phytocoenological research, taking into account the progress in the floristic knowledge of the mountain, using modern phytocoenological methods and respecting the International code of phytosociological nomenclature.

The article is dedicated to Acad. Kiril Micevski, one of the pioneers of modern vegetation studies in Macedonia. Acad. Micevski specialized in the phytocoenological methodology according to Braun Blanquet under the mentorship of one of the well known phytocoenologists - Prof. Stjepan Horvatić. As a result of his research activities that lasted over 50 years he gave a general survey of the vegetation of Macedonia by elaborating many vegetation types. He made an outstanding contribution to the investigation of the water, marsh and halophytic vegetation, as well as of lowland meadows. His contribution to the study of dry grassland vegetation is also remarkable as he established the research principles and described an order and three alliances (Astragalo-Potentilletalia, Trifolion cherleri, Saturejo-Thymion and ArmerioPotenillion) on the basis of which numerous communities have been described.

\section{AREA OF RESEARCH}

The heterogeneity of vegetation cover of the Mountain Galičica, is undoubtedly a result of spatial and environmental uniqueness of the massif, its geological history and climate specifics. Mountain Galičica is a horst which was elevated by the tec- 
tonic movements in the past and which relatively clearly stands out from the surrounding mountains as a separate geo-morphostructural whole. To the east and west the mountain is clearly limited by two major natural lakes - Ohrid and Prespa (Figure 1), to the south by the valley of Korča in Albania, while to the north it is connected with Plakenska and Ilinska mountains through Preval of Bukovo [27]. Ohrid and Prespa Lakes, between which Mountain Galičica is located, are a kind of thermal regulator which regulates the climate on the broader space, not permitting extremely high or low temperatures, so that this region is under the influence of mild continental or modified (sub) Mediterranean climate. Favorable climatic circumstances and dominant limestone geological substrate, create good environmental conditions and ambient for development of a number of plant species and plant communities typical of Mediterranean or subMediterranean flora and vegetation. It can be seen in all parts of the mountain, as in the valleys and in its highest parts. The geographic position, limestone relief and mild pleasant climate, allow Galičica to function during the glacial period as a part of the grid of refugial areas of the territory of Macedonia [28].

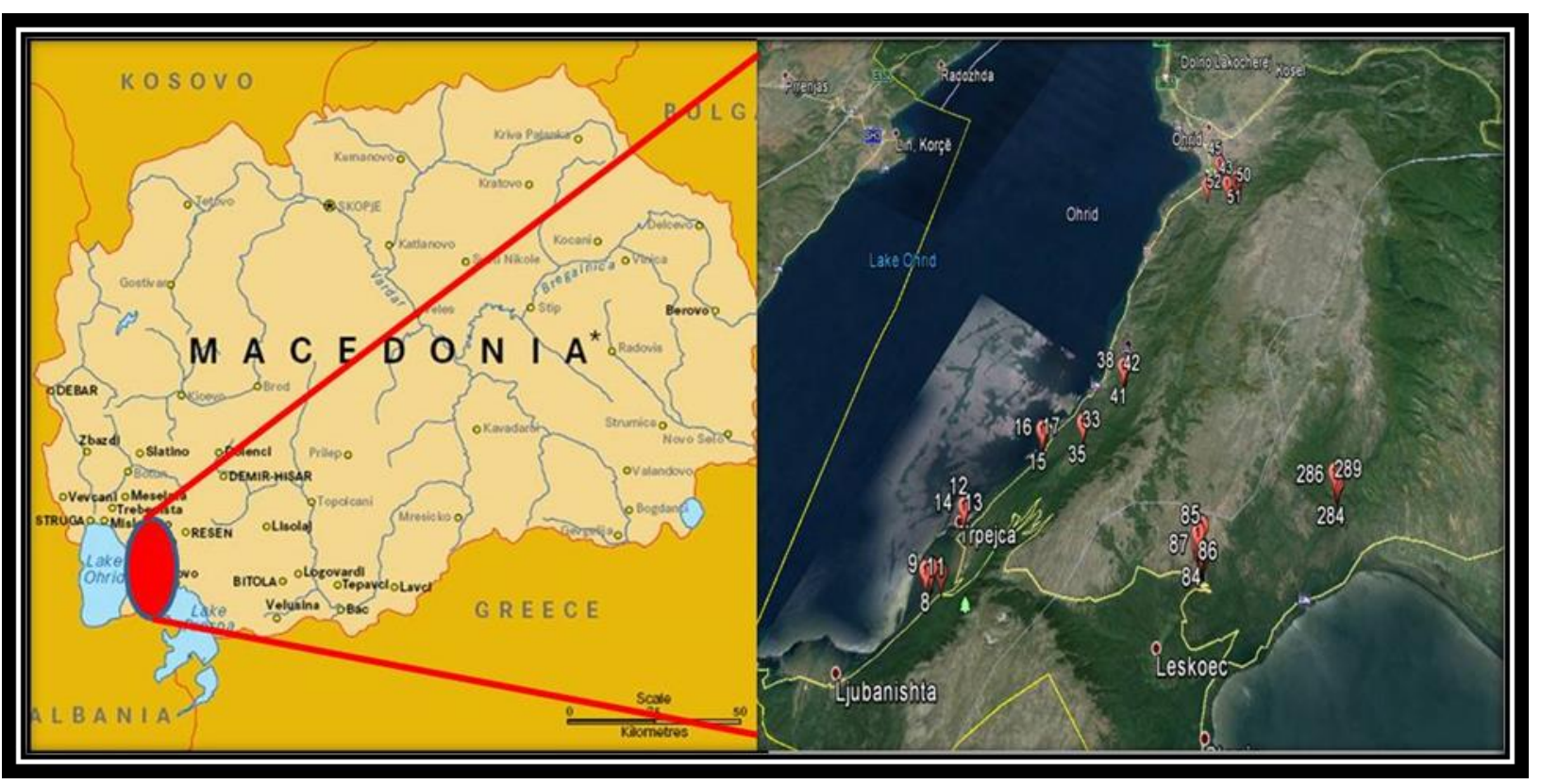

Figure 1a and b. Map of the investigated area and localities on Galičica Mountain

\section{MATERIAL AND METHODS}

Phytosociological investigations were realized during 2009 and 2010 in the framework of a broader research into the grassland vegetation. The dry grassland vegetation on Mountain Galičica was investigated as well as the most common secondary vegetation types created by gradual and long-lasting degradation (grazing and browsing by animals, fires, or mowing) of various forest phytocenoses.

Phytosociological investigations were conducted according to the standard method of vegetation surveys of Zurich-Montpellier school [29], whereby for the chosen homogeneous, representative areas lists of plant species with estimated cover values, named as relevés, were made; so, in our case, 50 vegetation relevés were prepared for this purpose.
For the preparation of the vegetation relevés representative minimal areas were selected up to $100 \mathrm{~m}^{2}$. For each vegetation relevés, besides the data for the floristic composition and their quantitative participation, there were also registered the basic data for the locality and the abiogenic and physiognomical features of the habitats: the name of the investigated locality, date, altitude $(\mathrm{m})$, the area of the relevé $\left(\mathrm{m}^{2}\right)$, inclination $\left(^{\circ}\right)$, exposure, total cover, geological substrate, geo-coordinates anthropogenic influence, etc.

After drying and labeling the collected plant material was determined, using thereby a large number of floristic works - Flora Europaea [30-34]; Prodromus florae peninsulae Balcanicae [35-37]; Flora of the Republic of Macedonia [3844]; Flora of Bulgaria [45-47]; Flora of SR Serbia [48], etc. The taxonomic nomenclature and the 
compliance of registered taxa of our vegetation relevés were done with the taxonomy and nomenclature of the species and lower taxa and their synonyms using the "online" EURO + MED PLANT BASE (database for vascular plants of Europe and the Mediterranean region - http : //www.euromed.org.uk/).

For determination of the taxa of taxonomic complicated genera there were used the latest monographs and other floristic and taxonomic notes that refer to the flora of the Republic of Macedonia, the Balkan Peninsula and Europe. For comparison, there was also used the herbarium material deposited in the herbarium of the Institute of Biology $(\mathrm{MKNH})$ at the Faculty of Natural Sciences and Mathematics in Skopje.

The list of our own vegetation relevés and those that are described in the literature has been entered into the Turboveg database [49]. Vegetation relevés were exported in computer software JUICE [50] for further analysis, where for defining of plant communities, firstly, an agglomerative hierarchical cluster analysis has been made in program PC-ORD [51] with Jaccard index of similarity, using Flexible Beta method for connections within a groups with $\beta$ $=-0.25$, and transforming the data with $\mathrm{b}=\log (\mathrm{Xi}, \mathrm{j}$ $+1)$. For an objective selection of the cluster method and the optimal number of clusters with maximum number of "faithful" species we used the method OptimClass [52].

Additionally, the diagnostic species of the communities were identified by a fidelity measure in the JUICE program [50]. The threshold of the phi value was subjectively selected at 0.50 for species to be considered as diagnostic [53]. The species having more than $50 \%$ occurrence frequency for a given community were defined as constant species, while species attaining a cover higher than $50 \%$ in more than $30 \%$ of the relevés were accepted as dominant species.

To determine the biological range of communities we used biological (life) forms by Raunkiaer [54]: geophytes, therophytes, hemicryptophytes, chamaephytic and phanerophytes.

The results obtained from numerous numerical analyses helped us in processing of analytic and later of synthetic tables. By using the appropriate literature, and the knowledge that we possess, each of the taxa listed in the table was determined by its syntaxonomic affiliation to the appropriate syntaxonomic category.

In the last column of the analytical tables there are data of the calculated and entered percentages of occurrence of the species in the total number of relevés of vegetation community - the socalled degree of constancy.
The names of registered syntaxa and their authors are given according to the International code for phytosociological nomenclature [15].

During chorological analyses the floral elements given by Gajič [55], Pignatti [56] and other authors were used. A total of 233 taxa of vascular plants were identified during our research, characterized by high phytogeographic diversity which were arranged in 9 chorological groups: I - Balkan and sub-Balkan floral elements, II - Steno Mediterranean floral elements, III - Eurimediterranean floral elements, IV - Mediterranean mountainous floral elements, V - Eurasian floral elements, VI Atlantic floral element, VII - Orophil-South European floral element, VIII - Boreal floral elements, and IX - floral elements with wider distribution. Through their percentile representation in the community the chorological composition of the registered phytocenoses was determined.

\section{RESULTS AND DISCUSSION}

For more precise and objective classification of the relevés made within our research of dry grassland vegetation of Mountain Galičica the latest computer numerical methods were also used besides classical methods of analysis. After the analysis was made, because of the presence of a large number of characteristic species (such as: Koeleria splendens, Medicago rigidula, Ziziphora capitata, Coronilla scorpioides, Minuartia hamata, Tragopogon balcanicus, Tremastelma palestinum, Fumana procumbens, Hippocrepis ciliata, Allium flavum subsp. flavum and Minuartia glomerata subsp. macedonica of the alliance Saturejo-Thymion) we have concluded that the investigated vegetation belongs to that alliance, which includes communities that develop on rocky and hilly pastures on limestone geological substrate. On the territory of the Republic of Macedonia within this alliance the following seven associations are described so far: Brachypodio-Onobrychetum pindicolae Micevski [2], Astragalo-Morinetum Micevski [2], SilenoThymetum ciliatopubescentis Matevski, Lozanovski et Kostadinovski [57], Petrorhagio-Chrysopogonetum grylli Matevski et al. [6], ScorzoneroStipetum endotrichae Matevski et al. [6], Globulario-Centauretum grbavacensis Matevski et al. [6] and Astragalo-Helianthemetum marmorei Matevski et al. [6].

To determine the syntaxonomic position of the 50 vegetation relevés from the ivestigated area a base of vegetation relevés was created for the associations from the alliance Saturejo-Thymion, registered on the territory of the Republic of Macedonia. 
This database contains 278 vegetation relevés and 580 taxa which were exported to a computer program Juice, for further analysis.

The optimal level of the clustering was determined by the Optimclass 1 method [52]. Corre- spondingly, relevés were grouped using Jaccard index of similarity and the Flexible Beta method, as cut levels, percentage cover values of 0,5 , and 25 were defined and dendrogram was cut at the fourteen-cluster level (Figure 2).

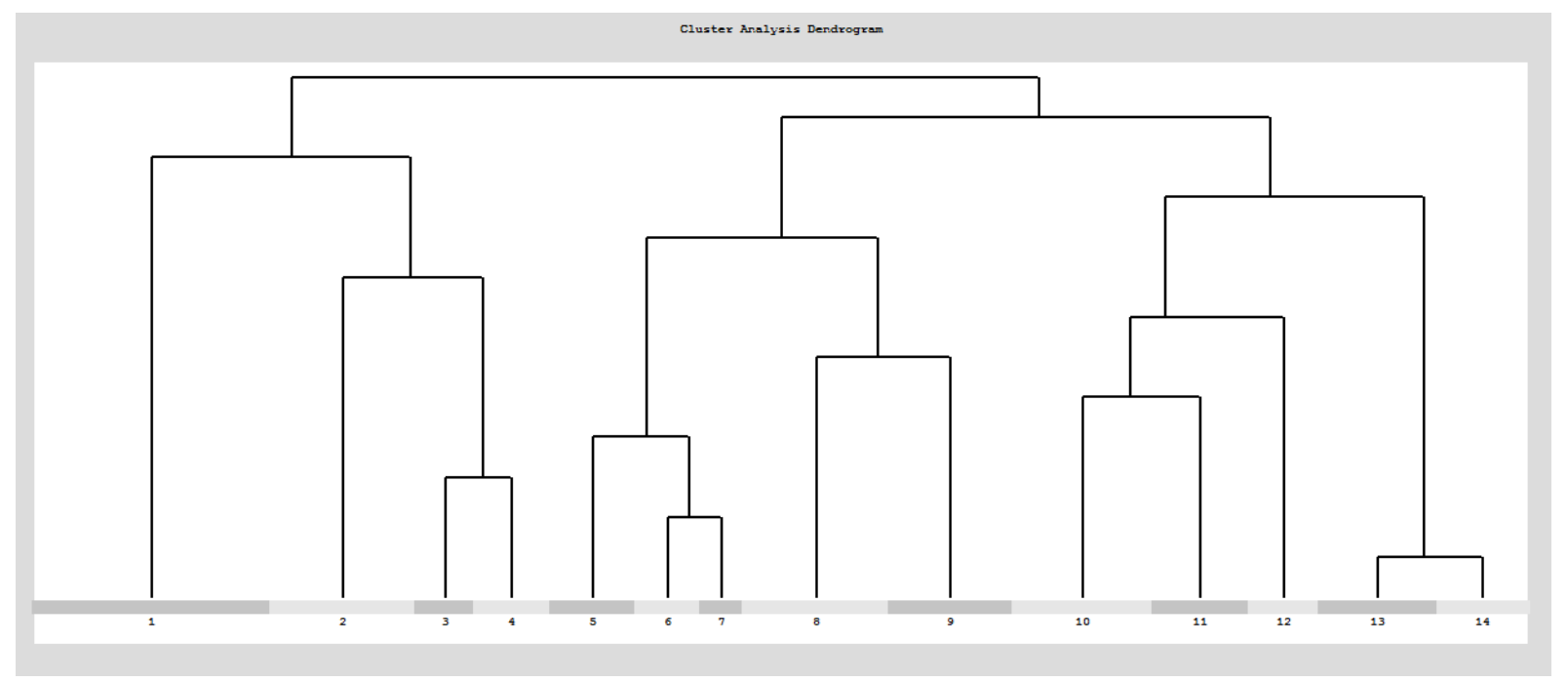

Figure 2. Saturejo-Thymion - Hierarchical classification in the form of dendrogram of 278 relevés in 14 clusters. Cluster 1 Brachypodio-Onobrychetum pindicolae; Cluster 2 - Astragalo-Morinetum; Cluster 3 и 4 -Hedysaro-Convolvuletum; Cluster 5 unpublished vegetation relevés on limestone substrate from the locality Luben;Cluster 6 - ass. Petrorhagio-Chrysopogonetum grylli; Cluster 7 - unpublished vegetation relevés on limestone substrate from the locality Barbaras; Cluster 8 - ass. Siderito Trifolietum dalmaticae ass. nova- subass. typicum subass. nova; Cluster 9 - ass. Siderito -Trifolietum dalmaticae ass. nova subass. erodietosum guicciardii subass. nova; Clusters 10,11 and 12 ass. Globulario-Centauretum grbavacensisMatevski et al 2014, in Cluster 11 ass. Sileno-Thymetum ciliatopubescentis; Clusters 13 and 14 - ass. Scorzonero-Stipetum endotrichae (the

Cluster 14 also includes unpublished vegetation relevés on limestone substrate from the locality Pantelejmon - Mariovo).

According to hierarchical classification (Figure 2) the researched dry grasslands on Mountain Galičica are subordinated to the clusters 8 and 9. When the synoptic table with program package Juice was prepared, we received three groups of taxa - diagnostic, constant and dominant. According to them, our vegetation relevés from Galičica Mountain are separated from the vegetation relevés from other parts of Macedonia covered by the remaining twelve clusters. Below, the diagnostic, constant and dominant taxa are presented which were obtained by the analysis.

Diagnostic species: Alyssum strigosum, Anthemis arvensis, Bupleurum gussonei, Cerastium brachypetalum subsp. roeseri, Clinopodium acinos, Elytrigia intermedia, Sideritis montana subsp. remota, Trifolium dalmaticum.

Constant species: Aegilops neglecta, Bromus squarrosus, Crupina vulgaris, Helianthemum salicifolium, Hypericum rumeliacum, Koeleria splendens, Medicago minima, Petrorhagia saxifraga, Poa bulbosa, Sedum urvillei, Teucrium capitatum, Valerianella coronata.
Dominant species: Anthyllis vulneraria subsp. polyphylla

After the prepration of the synoptic table and the comparative analysis made between our own records and the literature data relating to known communities of the alliance Saturejo-Thymion, we concluded that the vegetation relevés of Mountain Galičica are characterized by a sufficient number of diagnostic species which is the basis for the separation of a new association - Siderito montanaeTrifolietum dalmaticae ass. nova (Table 1).

The association Siderito montanaeTrifolietum dalmaticae (Holotypus hoc loco: Tab. $1 / 21$ ) is named after the two characteristic species Sideritis montana subsp. remota, which is a representative of the south Balkan-Asia Minor floral element and has limited distribution on the territory of the Republic of Macedonia, in the vicinity of Dojran and Mount Galičica, and the Balkan endemic species Trifolium dalmaticum.

As diagnostic species the following taxa are separated, too: Cerastium brachypetalum subsp. roeseri, Anthemis arvensis, Alyssum strigosum, 
Clinopodium acinos, Bupleurum gussonei and Elytrigia intermedia.

It is a secondary community which develops at the clearings on Galičica Mountainin degraded stands in the belt of oak forests (ass. Quercetum frainettocerris, ass. Quercetum trojanae, ass. Ostryo carpinifoliae-Quercetum cerris), as well as in the lower belt of beech forest on an altitude of 700-1200 m.

The association Siderito montanae-Trifolietum dalmaticae is registered at several sites in the
Ohrid part of Galičica Mountain: Mal Osoj, Elšani, Trpejca, over the road to Vršec, Velestovo, Pogled, also to Margarine and over the curve $M$ from the Prespa side (Figure 3).

The biological spectrum illustrates best the environmental conditions, especially the climatic characteristics of the reaserched area. It is a therophytic-hemicryptophytic community in whose composition therophytes (49\%) and hemicryptophytes $(36 \%)$ dominate (Figure 4$)$.

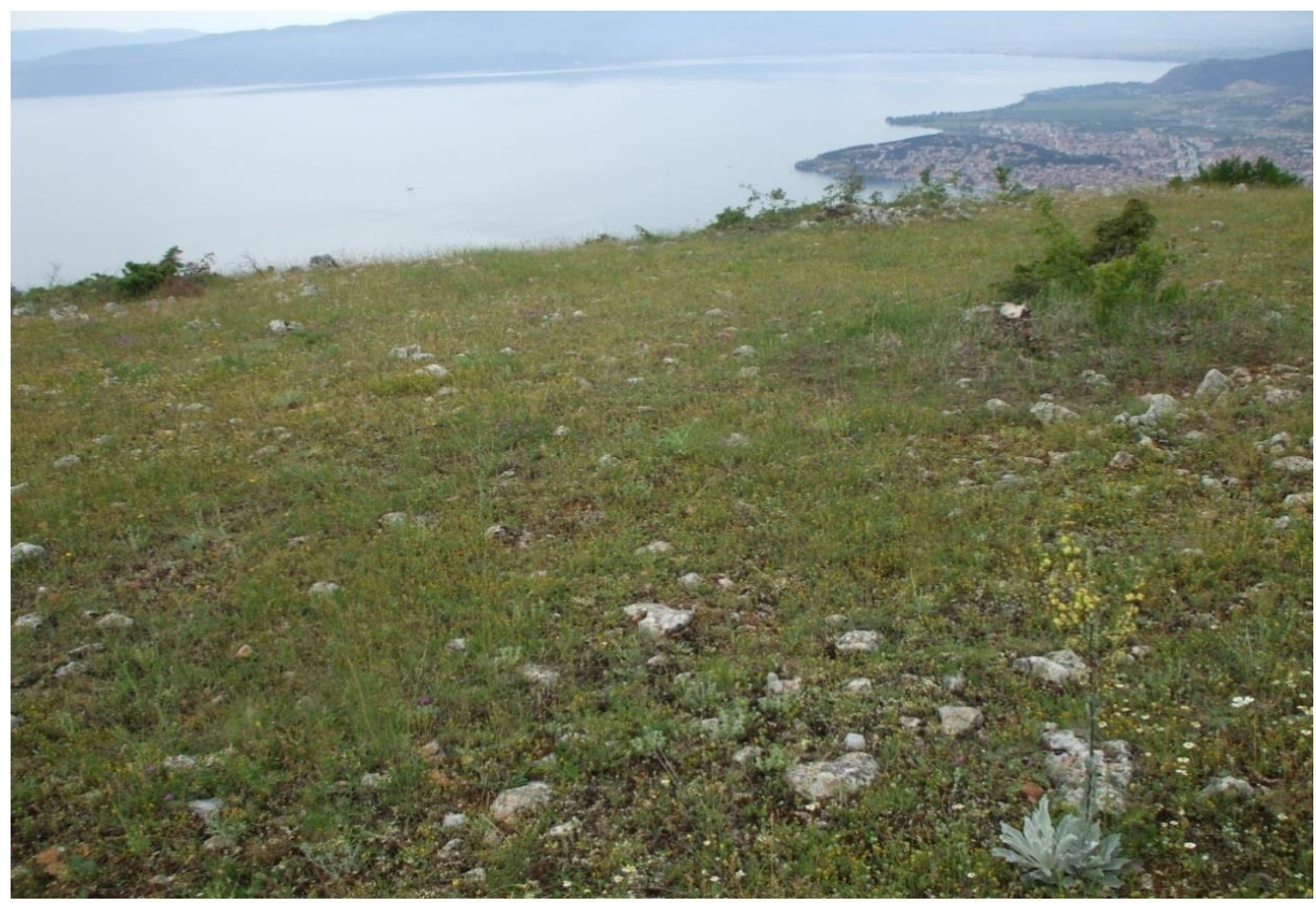

Figure 3. Ass. Siderito montanae-Trifolietum dalmaticae ass. nova - dry grassland above the v. Velestovo

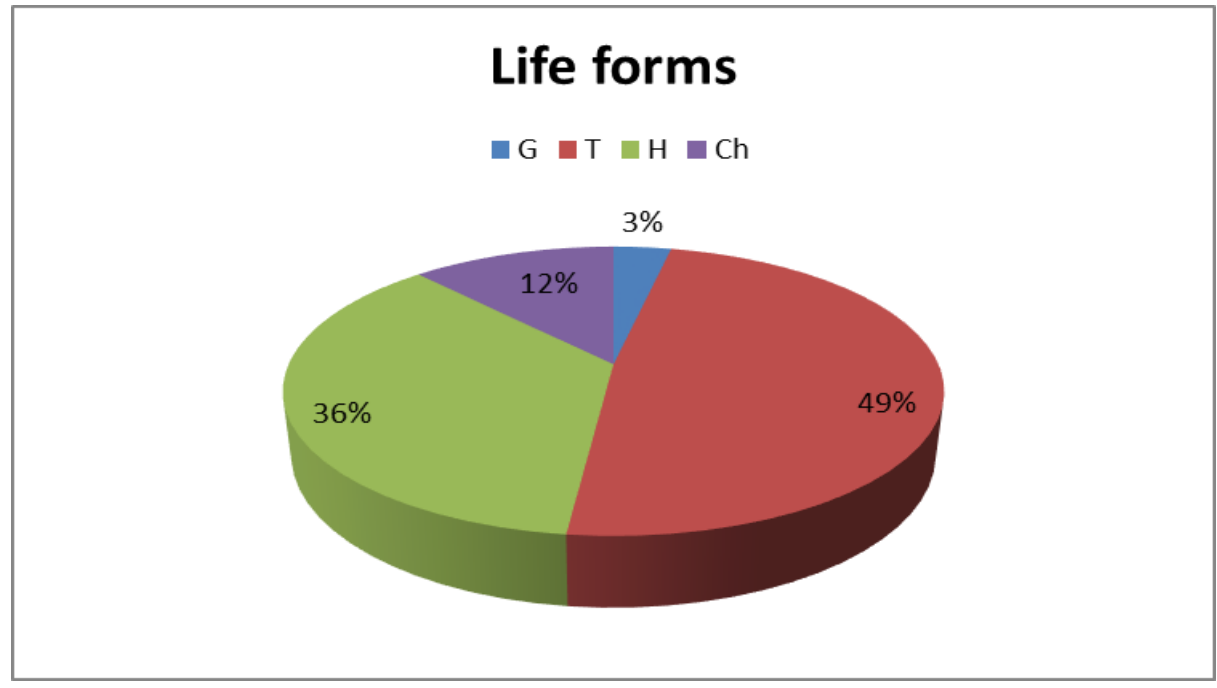

Figure 4. Ass. Siderito montanae-Trifolietum dalmaticae ass. nova - spectrum of life forms 
Through a detailed analysis of area-spectrum, we got a rather complete phytogeographic structure of the dry grasslands of Galičica (Figures 5 and 6).

The impact of the modified Mediterranean climate which is particularly intense in the altitudinal belt where this community develops is reflected in its floristic composition, as is evident by the largest presence of taxa from the Eurimediterranean floral element $(35 \%)$. Taxa belonging to Eurasian floral element are represented by $28 \%$, while the Balkan floral element comprises 17\% (Figure 5).

From the group of Balkan floral elements (Figure 6), the most dominant are the Balkan floral elements (sensu stricto) $(40 \%)$.

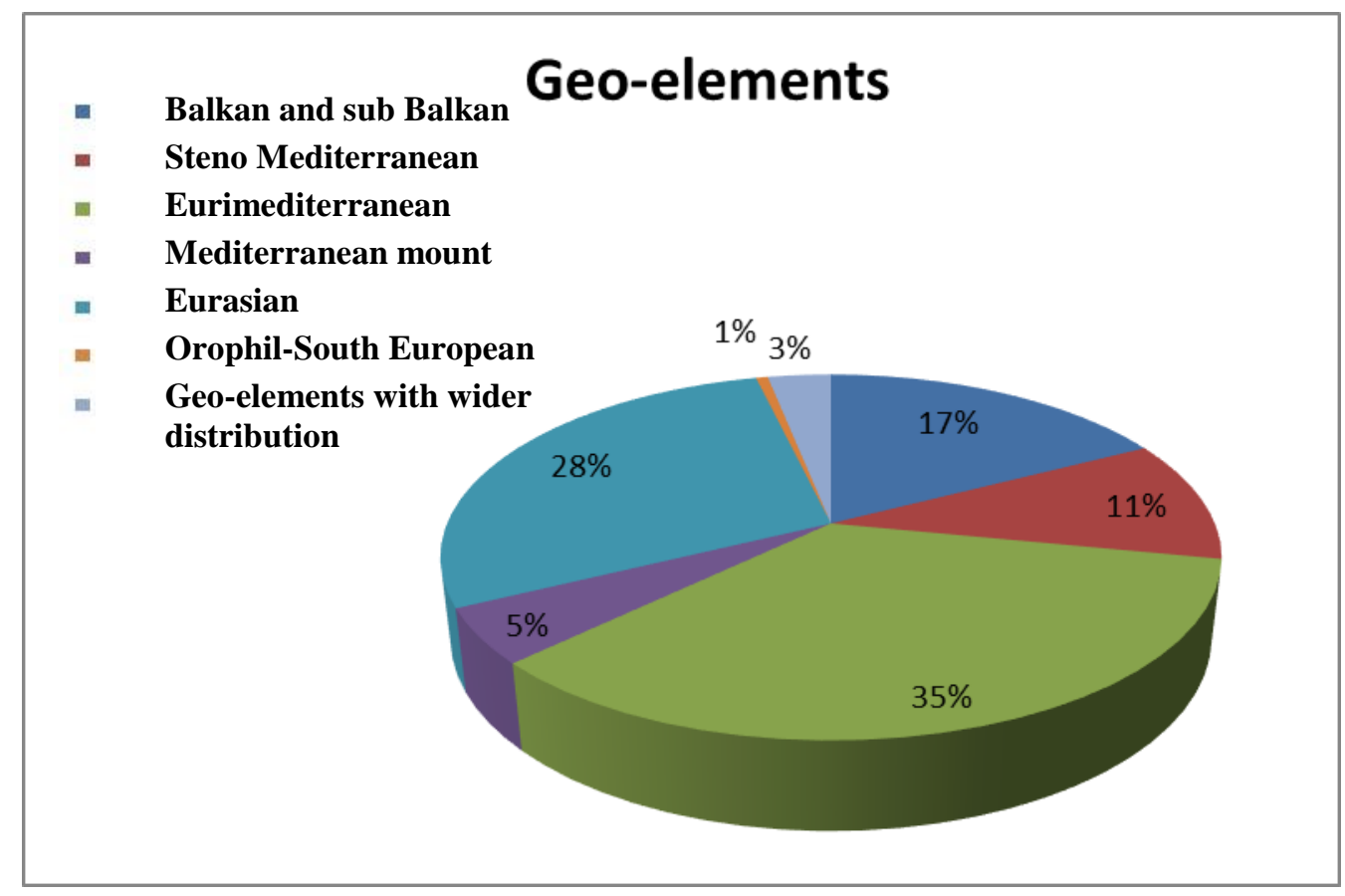

Figure 5. Ass. Siderito montanae-Trifolietum dalmaticae ass. nova - spectrum of geo-elements

\section{Balkan geo-elements}

- Balkan (sensu stricto)

- South Balkan

- Scardo-Pindus

- Macedonian endemites

- Balkan-Apennine

- South Balkan-Asia Minor

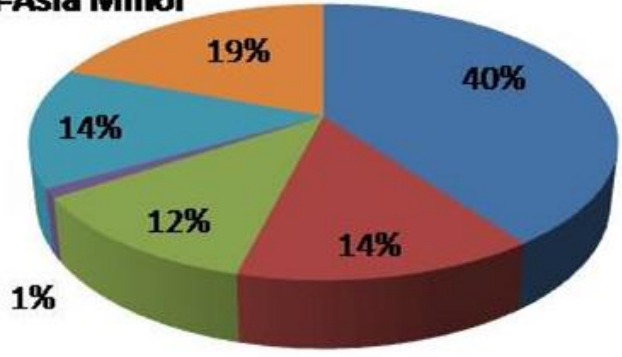

Figure 6. Ass. Siderito montanae-Trifolietum dalmaticae ass. nova - percentage representation of Balkan geo-elements (phytogeographic spectrum) 
Using the data from "WorldClim", we received the following bioclimatic variables for the researched community:

BIO1 = Annual mean temperature (9.2), $\mathrm{BIO} 2=$ Mean diurnal range (mean of monthly (max temp $-\min$ temp) (10.2), BIO3 = Isothermality $(\mathrm{BIO} 2 / \mathrm{BIO} 7)(0.35), \mathrm{BIO} 4=$ Temperature seasonality (standard deviation *100) (64.6), BIO5 = Max temperature of warmest month (25.1), BIO6 $=$ Min temperature of coldest month $(-3,8)$, BIO7 $=$ Temperature annual range (BIO5-BIO6) (28.9), BIO8 = Mean temperature of wettest quarter $(-5.7), \mathrm{BIO} 9=$ Mean temperature of driest quarter (17.4), $\mathrm{BIO} 10=$ Mean temperature of warmest quarter (17.4), BIO11 = Mean temperature of coldest quarter $(-0,9)$

BIO12 = Annual precipitation (854), BIO13 $=$ Precipitation of wettest month (113), BIO14 = Precipitation the driest month (45), BIO15 = Precipitation seasonality (coefficient of variation) (28), BIO16 = Precipitation of wettest quarter (291), BIO17 = Precipitation of driest quarter (134), BIO18 $=$ Precipitation of warmest quarter (134), BIO19 = Precipitation of coldest quarter (245);

The vegetation relevés of cluster 9 (Figure2), registered on several localities of Galičica - above Glajšo, Margarine, above the curve $\mathrm{M}$ - from Prespa side (Figure7), are separated from other vegetation relevés because of their floristic composition obtained at the sites where the typical form of the association Siderito montanaeTrifolietum dalmaticae develops. In the floristic composition of these relevés several taxa are appearing, such as: Convolvulus althaeoides subsp. tenuissimus, Erodium guicciardii, Alyssum repens subsp. trychostachyum, Cynoglottis barrelieri subsp. serpentinicola, Scandix australis, Erysimum comatum and Thesium divaricatum, which are registered in this combination on Mountain Galičica only at these sites, and are taken as diagnostic species of a new subassociation - subass. erodietosum guicciardii subass. nova (Holotypus hoc loco: Tab. 1/44) (Table 1). Special diagnostic species for this subassociation are two differential thermophilic species Erodium guicciardii (Figure 8) and Convolvulus althaeoides subsp. tenuissimus, which mainly develop in the southern part of the Balkan Peninsula and the Mediterranean. The most representative populations of these two species on the territory of Macedonia are found on Mountain Galičica. Erodium guicciardii was discovered for the first time for the territory of Macedonia by Micevski [3] on the Mountain Galičica, vicinity of Demir Hisar and Kičevo (Baba Sač, Ilinica, Suvo Pole), while Convolvulus althaeoides subsp. tenuissimus for the vicinity of Gevgelija and Galičica ([58], [44]). Other diagnostic species of the subassociation are: Alyssum repens subsp. trychostachyum, Cynoglottis barrelieri subsp. serpentinicola, Scandix australis, Erysimum comatum and Thesium divaricatum.

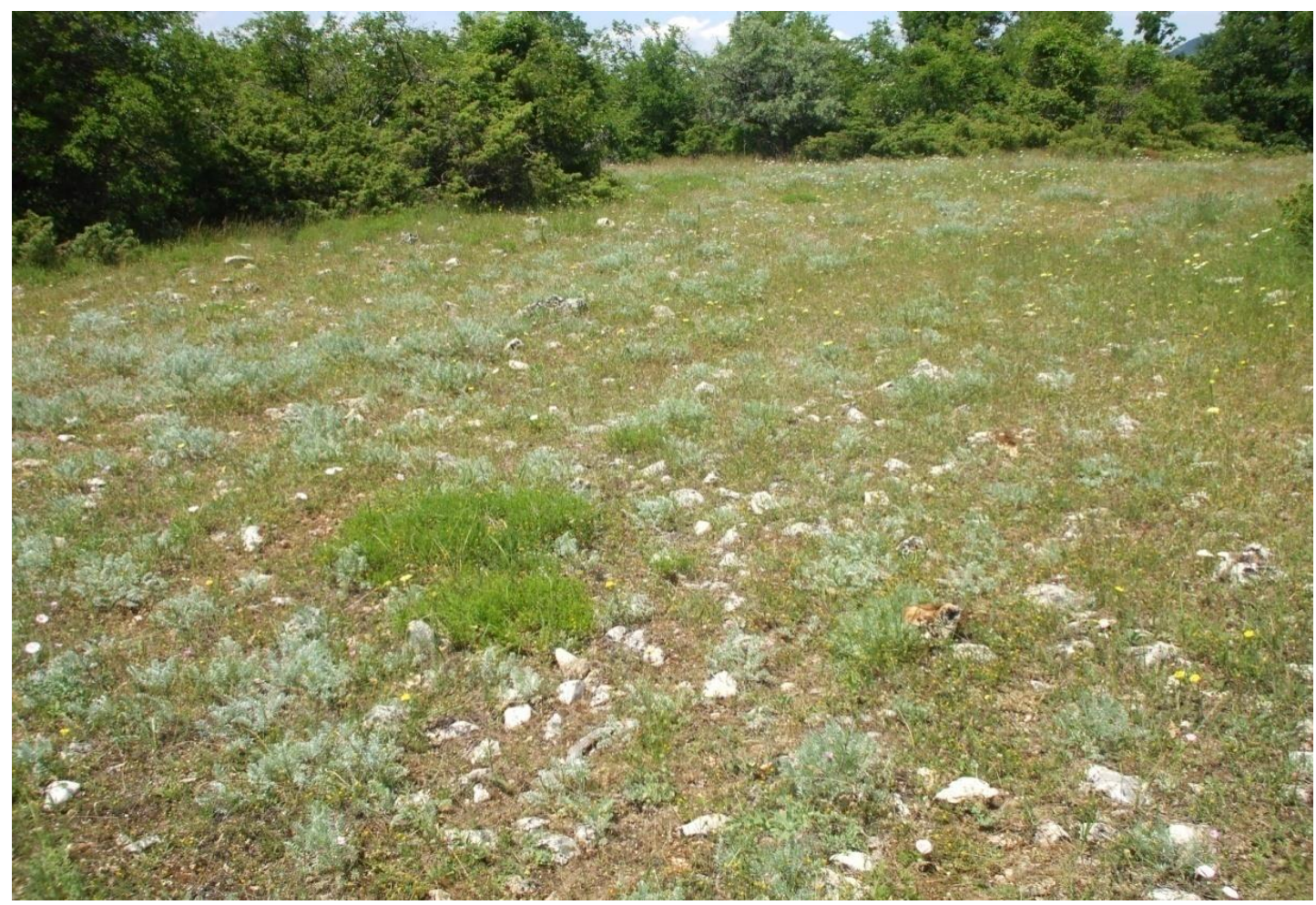

Figure 7. Ass. Siderito montanae-Trifolietum dalmaticae - subass. erodietosum guicciardii subass. nova - Margaraina above Oteševo, dry grassland 


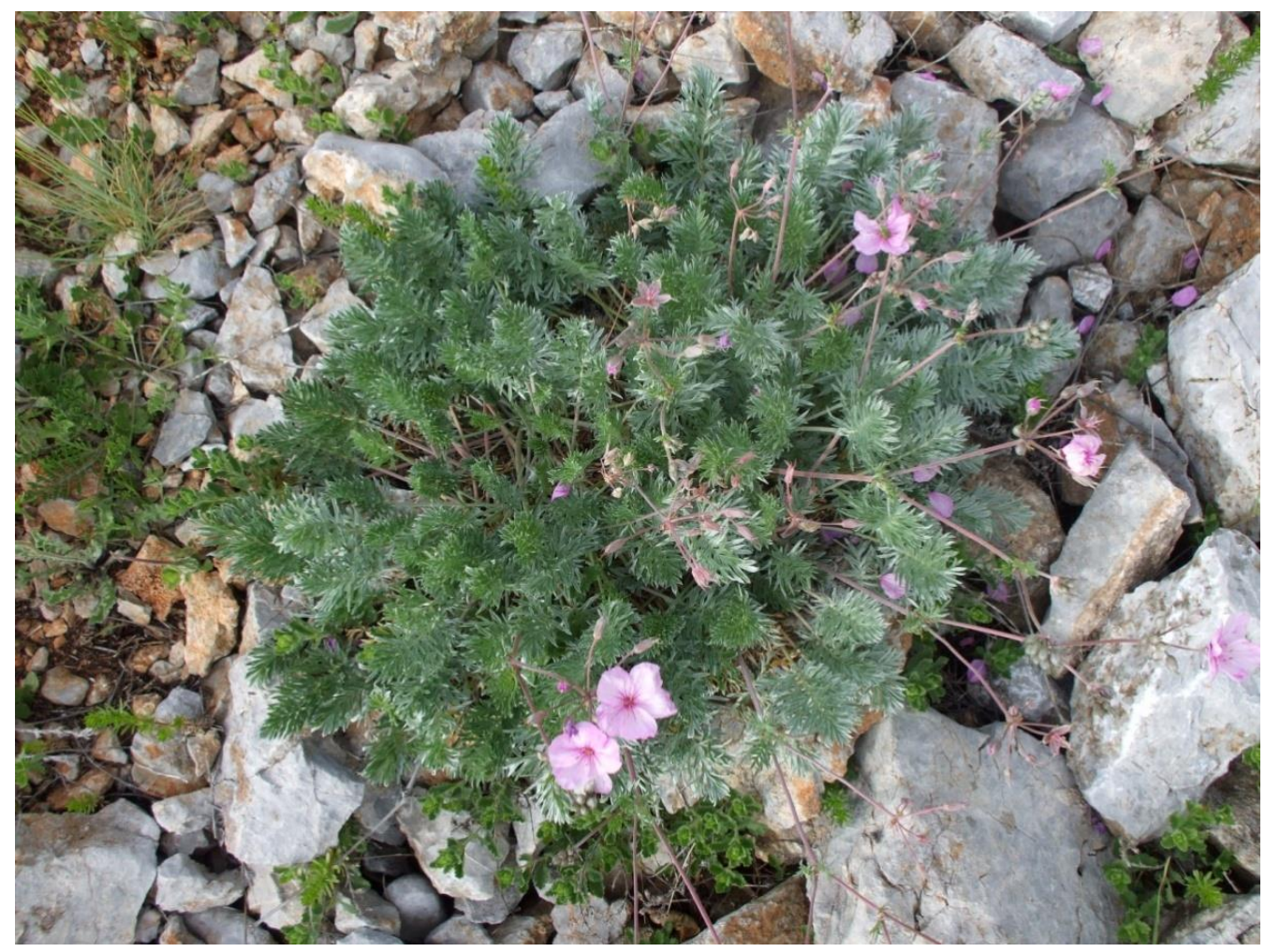

Figure 8. Erodium guicciardii Heldr.

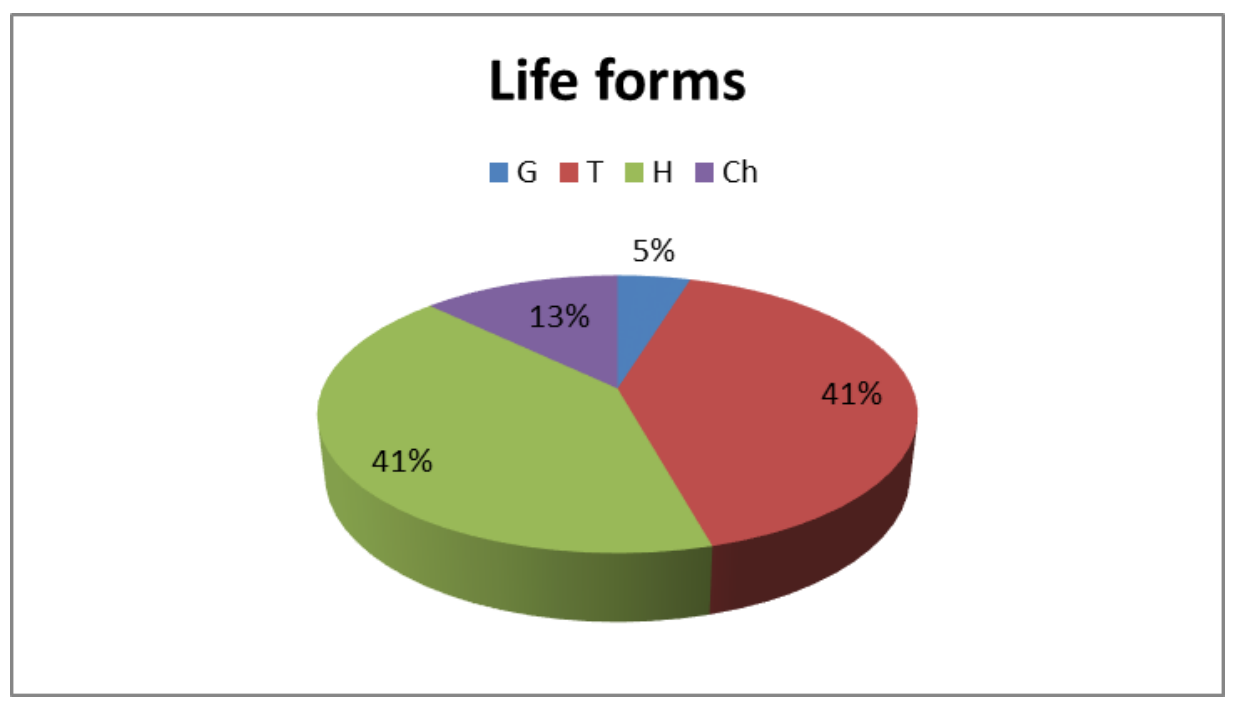

Figure 9. Ass. Siderito - Trifolietum dalmaticae ass. nova - subass. erodietosum guicciardii subass. nova - spectrum of life forms

From the biological spectrum (Figure 9) of the subassociation erodietosum guicciardii, it can be noticed that the percentages of hemicryptophytes and terrophytes are equal $(41 \%)$, while the representation of the hemicryptophytes in the subassociation is higher than in the typical form of the association Siderito montanae-Trifolietum dalmaticae.

The spectrum of floral elements is shown for the subassociation erodietosum guicciardii (Figures 10 and 11).
From the spectrum of floral elements (Figures 10 and 11) of the subassociation erodietosum guicciardii, it can be noticed that the percentage of Balkan and sub-Balkan elements is higher $(23 \%)$, and thereby the percentages of Balkan (sensu stricto) and South Balkan elements are higher too, than in the typical form of the association Siderito montanae-Trifolietum dalmatica. 
- Balkan and sub Balkan

\section{Geo-elements}

- Steno Mediterranean

- Eurimediterranean

- Mediterranean mount.

- Eurasian

$1 \%$

- Atlantic

- Orophil-South European

- Geo-elements with wider distribution

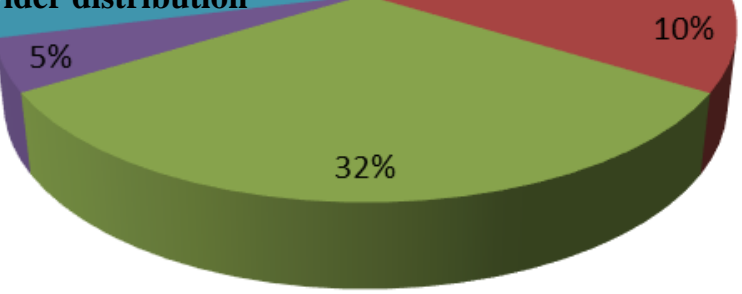

Figure 10. Ass. Siderito - Trifolietum dalmaticae ass. nova - subass. erodietosum guicciardii subass. nova. Spectrum of geo-elements (phytogeographic spectrum)

\section{Balkan geo-elements}

- Balkan (sensu stricto)

- South Balkan

- Scardo-Pindus

- Macedonian endemites

- Balkan-Apennine

- South Balkan-Asia Minor

- South Balkan-Caucasian

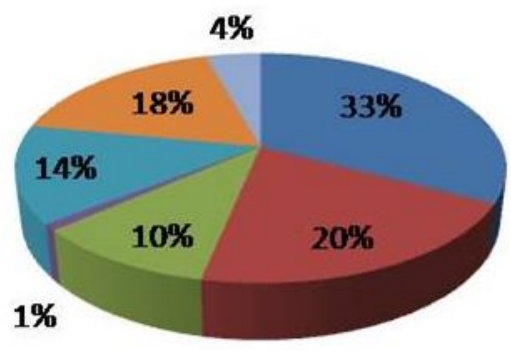

Figure 11. Ass. Siderito montanae - Trifolietum dalmaticae ass. nova - subass. erodietosum guicciardii subass. nova. Percentage representation of Balkan geo-elements (phytogeographic spectrum) 


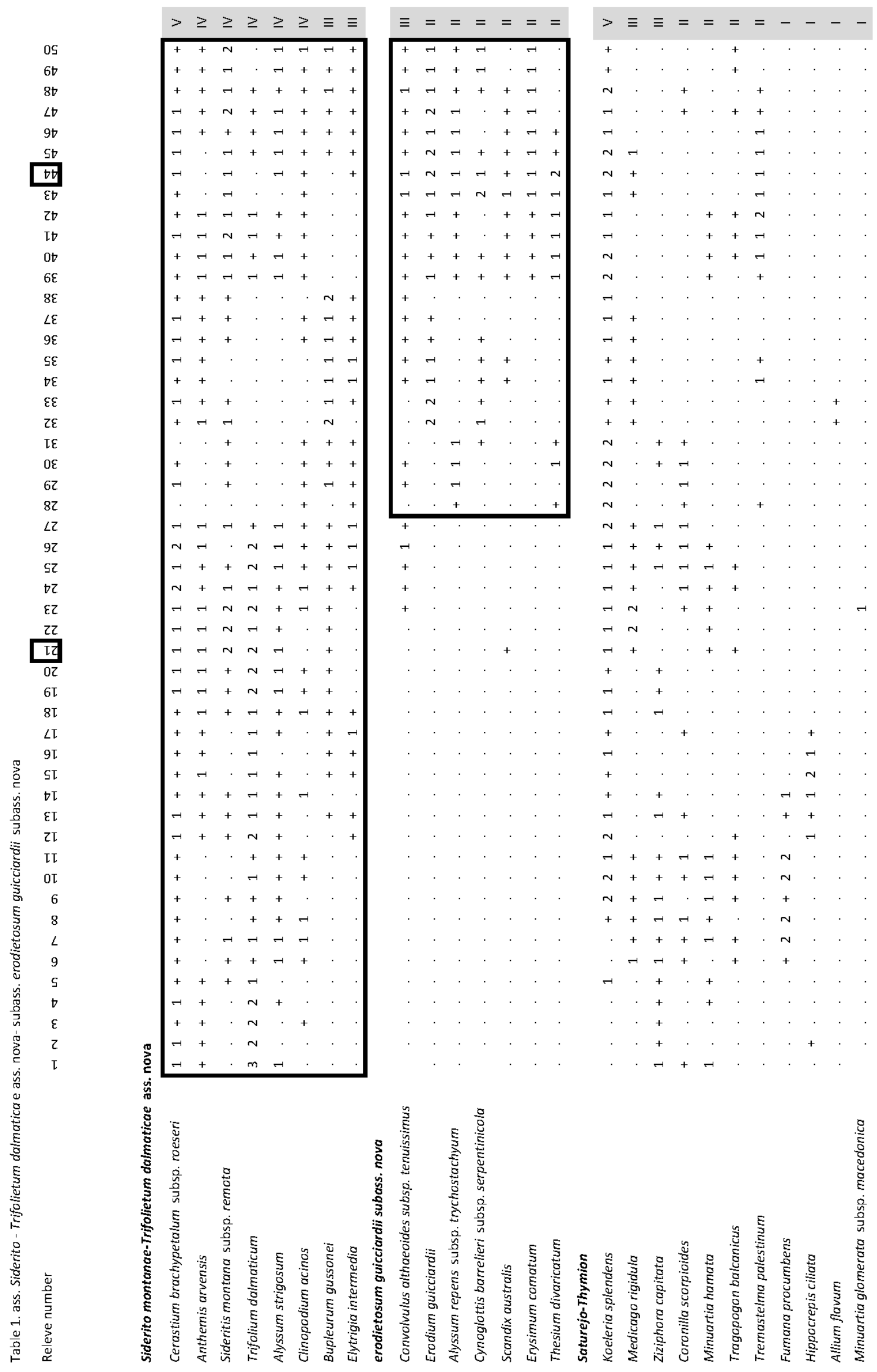



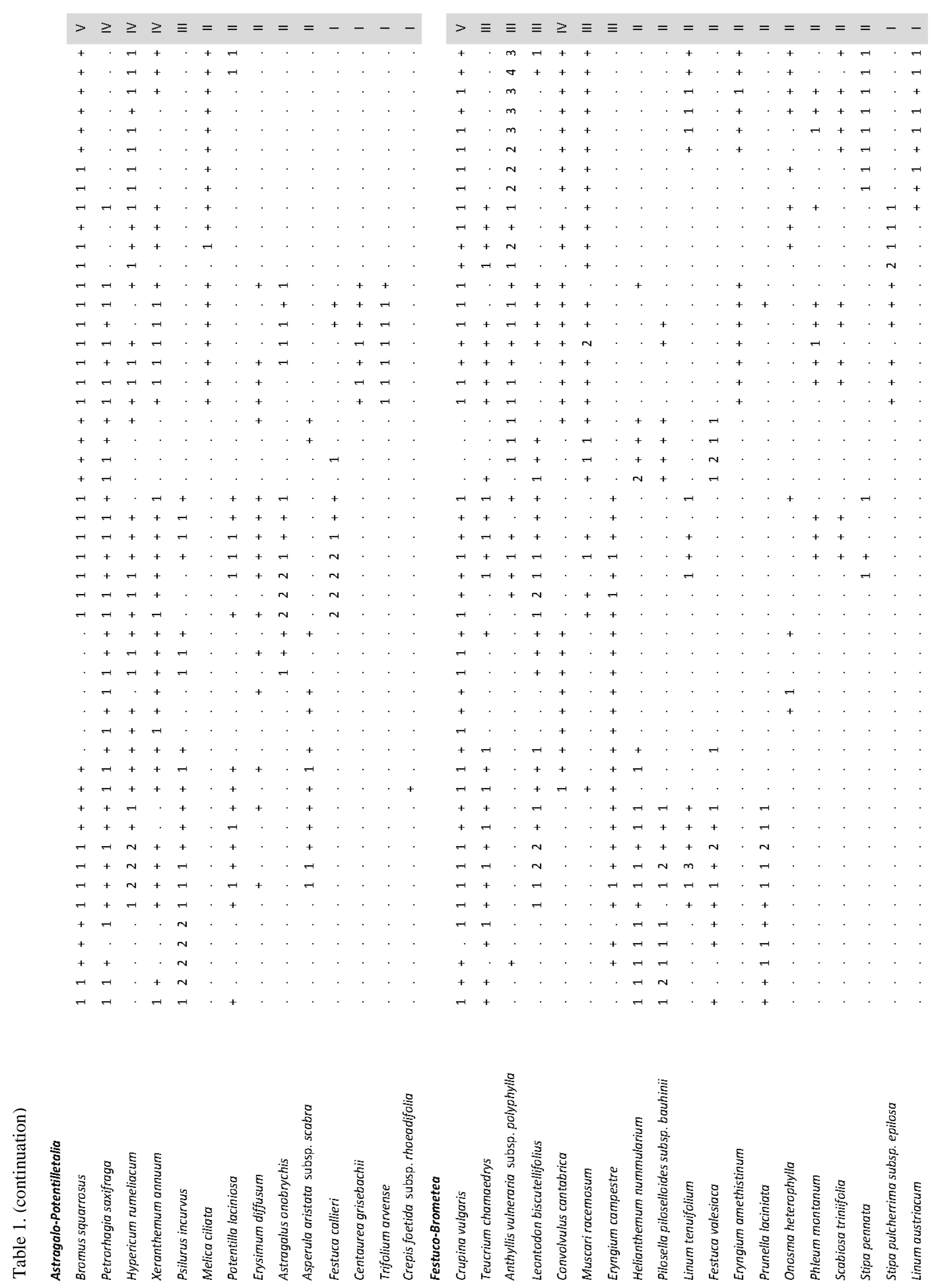

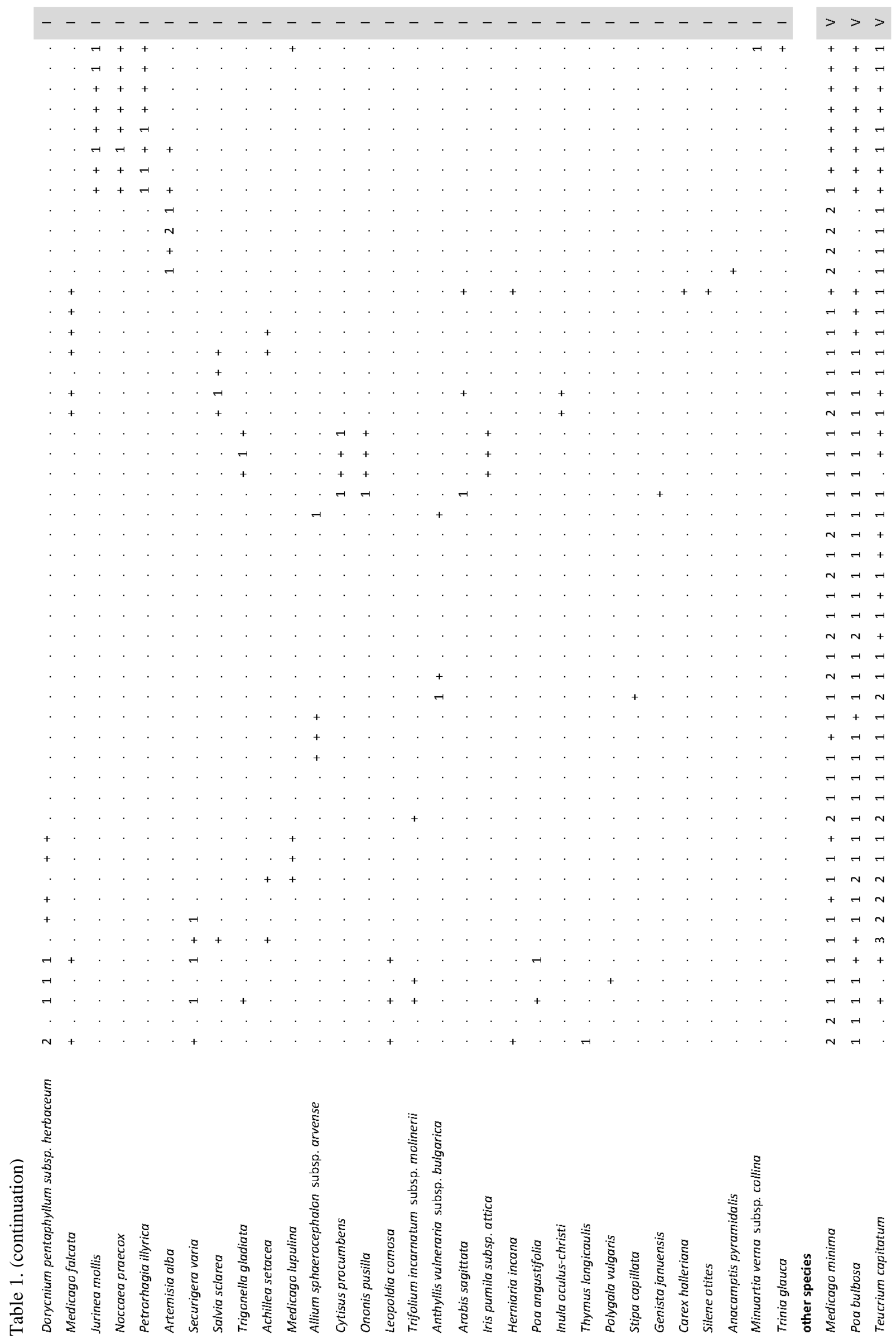

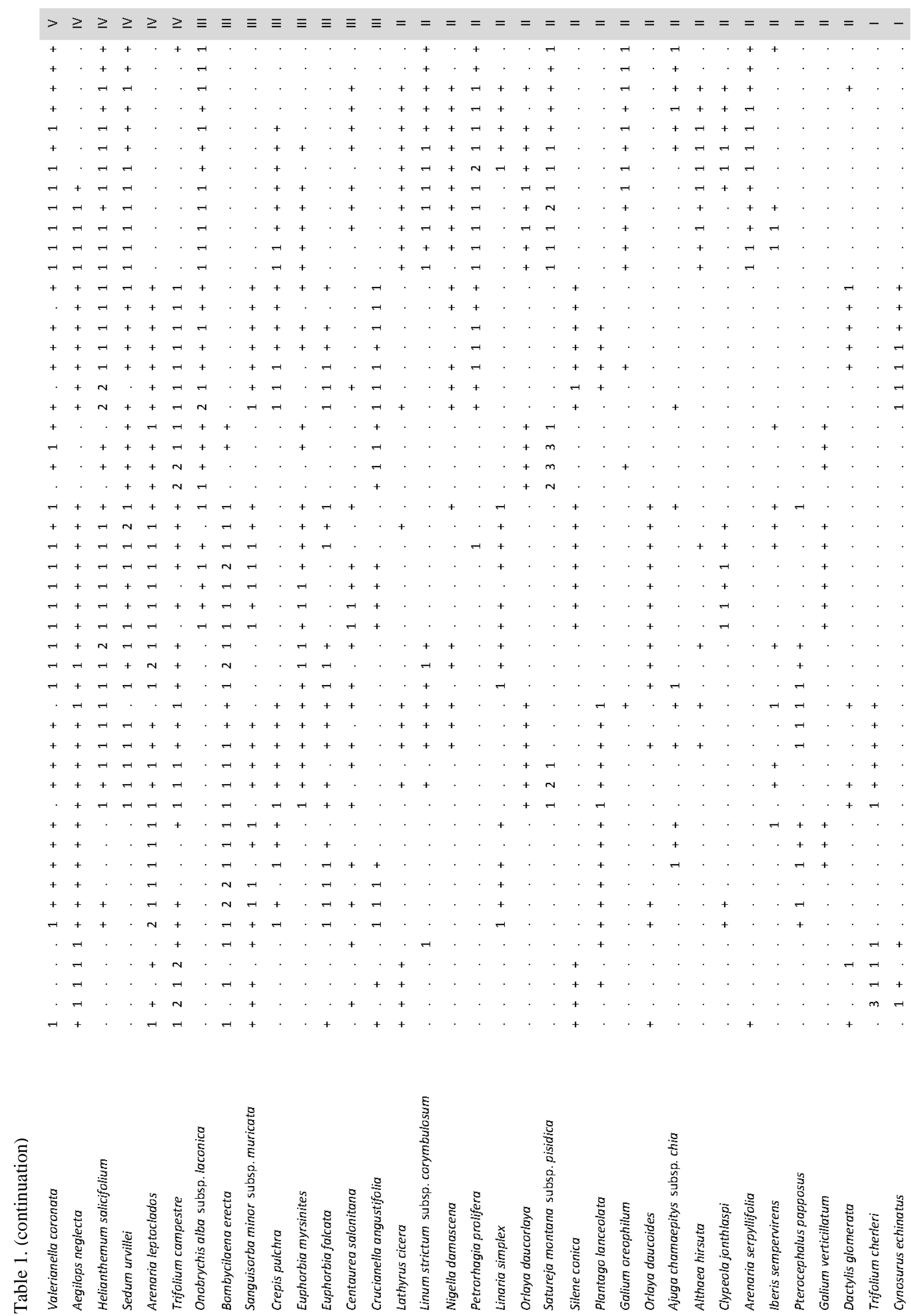


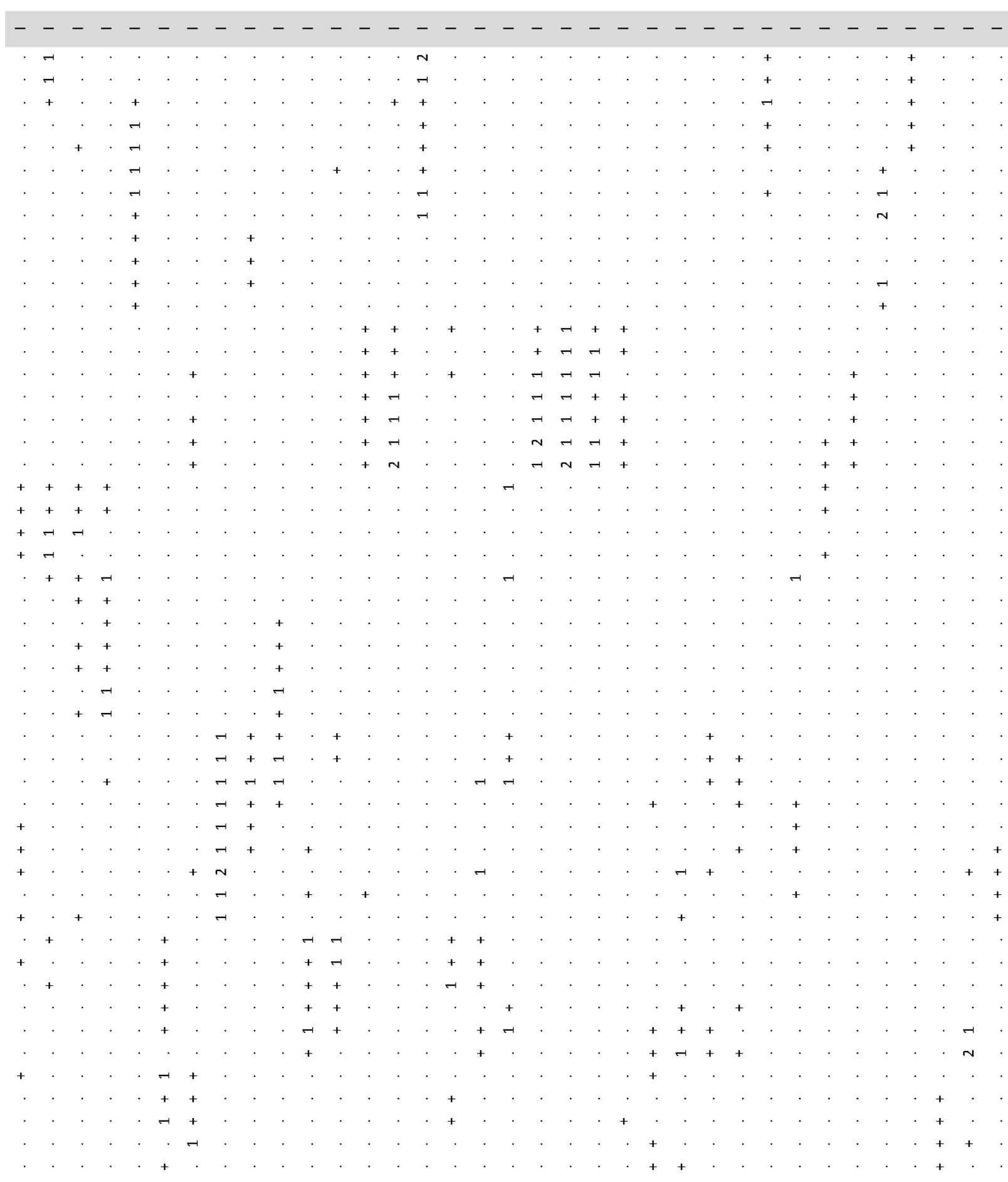




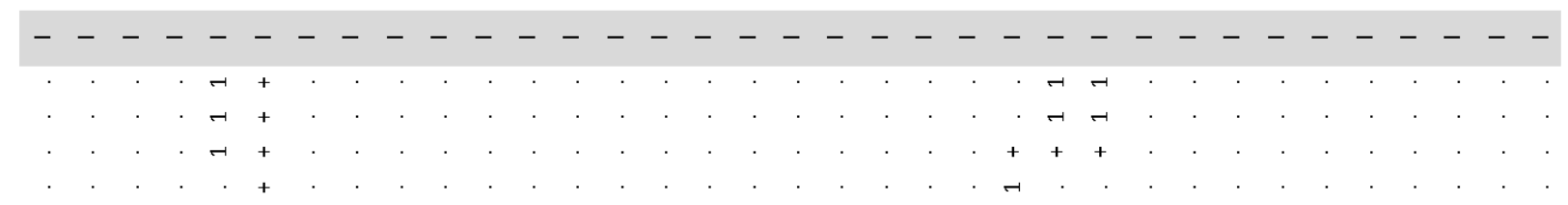




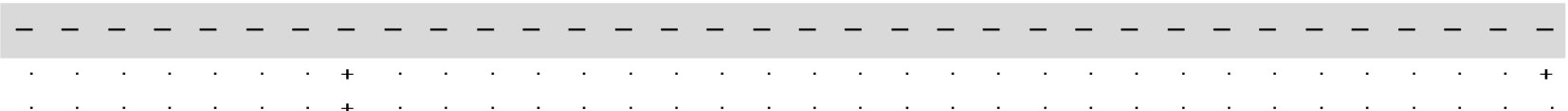

+
$\cdot++$
$+\quad++$

$\begin{array}{ll}+ \\ - & +\end{array}$

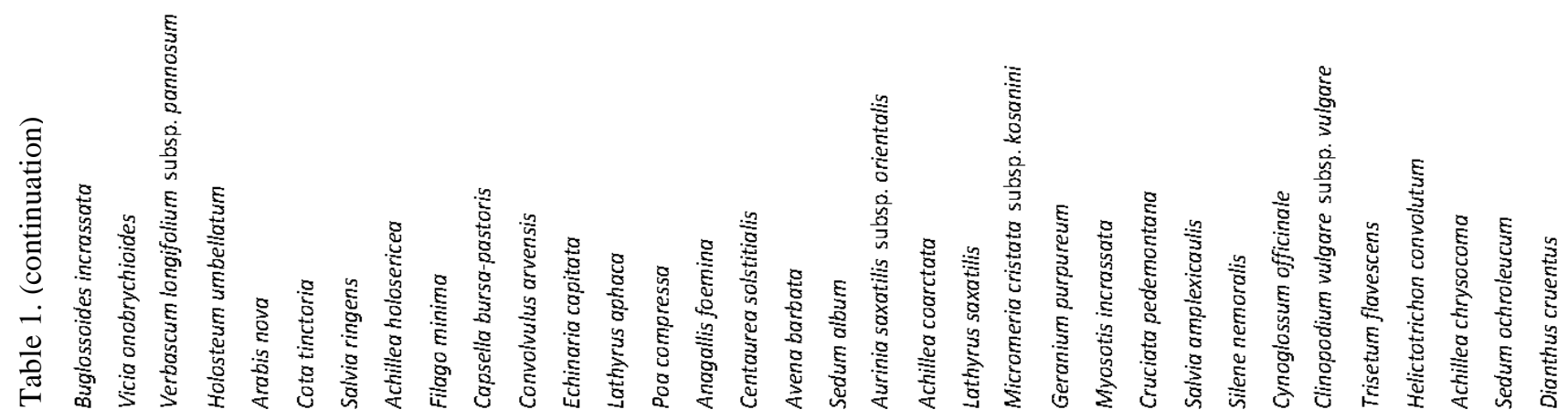




\section{CONCLUSION}

This paper represents an oveview of the distribution and syntaxonomic position of the dry grasslands that develop on carbonate geological substrate on the territory of the Republic of Macedonia. They are covered by the alliances SaturejoThymion Micevski [2], which is an additional information of the occurrence of this type of vegetation on the territory of the Republic of Macedonia. Furthermore, with numerical analyses it has also been shown that dry grasslands from Mountain Galičica significantly differ from the rest of the communities representing Saturejo-Thymion. The fact that species Sideritis montana subsp. remota, and Trifolium dalmaticum were significantly represented in the reaserched stands led us to distinguish a new association Siderito montanae-Trifolietum dalmaticae ass. nova which was confirmed with additional ecological analyses. Within this association the subassociation erodietosum guicciardii subass. nova, was also a separate one that floristically, physiognomically and structurally differed from the typical form of the association.

This study complements the picture of dry grasslands in the Republic of Macedonia, but there are still areas that are not sufficietly researched.

\section{APPENDIX}

Descriptions of the reléves in the Table 1. Running number, original reléve number, locality, latitude, longitude, sampling date, area, altitude (m), aspect, inclination (\%), cover.

1, 7, above Mal Osoj, 40.943518, 20.791347, 13.06.2009, 100, 924, W, 3, 80; 2, 8, above Mal Osoj, 40.94358, 20.786834, 13.06.2009, 100, 863, /, 0, 100; 3, 10, above Mal Osoj, 40.943194, 20.786489, 13.06.2009, 100, 854, S, 2, 95; 4, 11, Mal Osoj, 40.94245, 20.784913, 13.06.2009, 80, 846, /, 0, 90; 5, 9, Mal Osoj, 40.943481, 20.786471, 13.06.2009, 80, 860, SE, 2, 95; 6, 36, above v. Elšani, 41.015555, 20.822328, 17.06.2009, 100, 1010, NW, 10, 90; 7, 37, above v. Elšani, 41.015622, 20.82229, 17.06.2009, 100, 1005, W, 10, 95; 8, 38, above v. Elšani, 41.015933, 20.822255, 17.06.2009, 100, 1005, W, 10, 75; 9, 39, above v. Elšani, 41.015258, 20.822473, 17.06.2009, 100, 1012, E, 3, 80; 10, 40, above v.Elšani, 41.01475, 20.822452, 17.06.2009, 100, 1017, E, 5, 80; 11, 41, above v.Elšani, 41.014616, 20.821935, 17.06.2009, 100, 1016, E, 5, 80; 12, 12, above v. Tpejca, 40.961058, 20.785142, 14.06.2009, 100, 770, SW, 10, 90; 13, 13, above v. Tpejca, 40.960888, 20.785106, 14.06.2009, 75,770, W, 5, 85; 14, above v. Tpejca, 40.961046, 20.785218, 14.06.2009, 100,768, W, 10, 75; 15, 15, above v. Tpejca, 40.988548, 20.800466, 14.06.2009, 100,741, E, 3, 85; 16, 16, above v. Tpejca, 40.988604, 20.80054, 14.06.2009, 80,735, E, 5, 75; 17, 17, above v. Tpejca, 40.988692, 20.799871, 14.06.2009, 70,728, SW, 30, 80; 18, 42, the road to Vršec,41.102696, 20.819711, 18.06.2009, 100,803, W, 10, 90; 19, 43, the road to Vršec, 41.102616, 20.81987, 18.06.2009, 100,805, W, 10, 85; 20, 44, the road to Vršec, 41.102462, 20.820022, 18.06.2009, 100,808, W, 10, 80; 21, 45, above v. Velestovo, 41.092053, 20.834874, 19.06.2009, 100,1220, W, 10, 90; 22, 46, above v. Velestovo, 41.091977, 20.834999, 19.06.2009, 100,1222, W, 2, 90; 23, 47, above v. Velestovo, 41.092087, 20.83529, 19.06.2009, 100,1232, W, 5, 85; 24, 48, above v. Velestovo, 41.095369, 20.835676, 19.06.2009, 100,1193, W, 5, 85; 25, 49, above v. Velestovo, 41.095184, $20.833828,19.06 .2009,100,1112$, W, 15, 90; 26, 50, above v. Velestovo, 41.092037, 20.830171, 19.06.2009, 100,1082, W, 15, 95; 27, 51, above v. Velestovo, 41.090417, 20.819471, 19.06.2009, 100,932, SW, 15, 95; 28, 32, Glajšo-Pogled, 40.994076, 20.816384, 16.06.2009, 80,1055, W, 5, 80; 29, 33, GlajšoPogled, 40.99416, 20.816393, 16.06.2009, 80,1057, SW, 3, 80; 30, 34, Glajšo-Pogled, 40.994138, 20.816552, 16.06.2009, 90,1056, SW, 2, 85; 31, 35, Glajšo-Pogled, 40.994205, 20.8165, 16.06.2009, 90, 1056, SW, 2, 90; 32, 281, Margarina above Oteševo, 41.0106, 20.92367, 26.06.2010, 100,1027, S, 2, 100; 33, 282, Margarina above Oteševo, 41.011036, 20.923481, 26.06.2010, 100,1034, SW, 2, 100; 34, 283, Margarina above Oteševo, 41.011318, 20.923387, 26.06.2010, 100,1041, SW, 2, 100; 35, 284, Margarina above Oteševo, 41.012154, 20.922591, 26.06.2010, 100,1043, /, 0, 100; 36, 285, Margarina above Oteševo, 41.012575, 20.923359, 26.06.2010, 100,1047, SW, 2, 100; 37, 286, Margarina above Oteševo, 41.012872, 20.923333, 26.06.2010, 100, 1043, SW, 2, 100; 38, 287, Margarina above Oteševo, 41.01318, 20.921496, 26.06.2010, 100, 1047, W, 2, 100; 39, 58, over the bend M, Prespa side, 40.976222, 20.883362, 24.06.2009, 100,1238, SE, 20, 80; 40, 59, over the bend M, Prespa side, 40.976149, 20.88247, 24.06.2009, 100,1241, SE, 20, 80; 41, 60, over the bend M, Prespa side, 40.976239, 20.882323, 24.06.2009, 100,1251, SE, 25, 90; 42, 61, over the bend M, Prespa side, 40.976292, 20.881983, 24.06.2009, 100,1252, SE, 25, 95; 43, 79, over the bend M, Prespa side, 40.976618, 20.883337, 28.06.2009, 100,1255, SE, 20, 95; 44, 80, over the bend M, Prespa side, 40.976688, 20.883196, 
28.06.2009, 100, 1269, SE, 20, 90; 45, 81, over the bend M, Prespa side, 40.97714, 20.882492, 28.06.2009, 100,1296, SE, 25, 90; 46, 82, over the bend M, Prespa side, 40.977308, 20.88189, 28.06.2009, 100, 1336, SE, 25, 95; 47, 83, over the bend M, Prespa side, 40.977954, 20.880192, 28.06.2009, 100, 1383, SE, 25, 95; 48, 84, over the bend M, Prespa side, 40.979023, 20.87924, 28.06.2009, 100, 1416, S, 25, 90; 49, 85, over the bend M, Prespa side, 40.979653, 20.879324, 28.06.2009, 100, 1468, S, 15, 90; 50, 86, over the bend M, Prespa side, 40.981345, 20.879862, 28.06.2009, 100, 1507, W, 15, 90;

\section{REFERENCES}

[1] K. Micevski, Astragalo-Potentilletalia, new vegetation order on the hilly pastures in Macedonia. Contributions, Dep. of Nat. Sci. and Math., MASA, Skopje, 2 (2) (1970), pp. 15-23.

[2] K. Micevski, "Steppe" vegetation in Macedonia. God. zb. PMF-Biol., Skopje, 23, (1971), pp. 131150.

[3] K. Micevski, Erodium guicciardii Heldr. i njegov polimorfizam na području Makedonije Acta bot. Croat. Vol. 39 (1980), pp. 165-170.

[4] V. Matevski, A. Čarni, O. Avramoski, N. Juvan, M. Kostadinovski, P. Košir, A. Marinšek, A. Paušič, \& U. Šilc, Forest vegetation of the Galičica mountain range in Macedonia. Založba ZRC SAZU, Ljubljana, 2011.

[5] A. Čarni, V. Matevski, N. Juvan, M. Kostadinovski, P. Košir, A. Marinšek, A. Paušič, U. Šilc, Transition along gradient from warm to mesic temperate forests evaluated by GAMM, Journal of Plant Ecology (2015).

[6] V. Matevski, A. Čarni. R. Ćušterevska, M. Kostadinovski, \& L. Mucina, Syntaxonomy of the rocky grasslands on carbonate bedrocks in the west and southwest of the Republic of Macedonia. Applied Ecology and Environmental Research 13 (4) (2015), pp. 1197-1214.

[7] S. Redžić, The syntaxonomical differentiation of the Festuco-Brometea Br.-Bl. \& R. Tx. ex Klika \& Hadac 1944 in the Balkans. Ann. Bot. Roma (1999), pp.167-180.

[8] J. Klika, Studien über die xerotherme Vegetation Mitteleuropas II. Xerotherme Gesellschaften in Böhmen. Beih. Bot. Centralbl. 50B (1933), pp. 707-773.

[9] B. Pawlowski, Guide des excursions en Pologne. I. Partie. Guide de l'excursion botanique dans les monts Tatras (Environs du lac „Morskie Oko“ et du massif des „Czerwone Wierchy“) accompagné de le caractéristique géobotanique générale des Tatras. Orbis, Kraków, (1928), pp. 64.

[10] K. Micevski, Tipološki istražuvanja na vegetacijata na livadite i pasištata vo Maleš I Pijanec, MANU, posebni izd., 1978, pp. 9-41.

[11] K. Micevski, Tunico-Trisetetum myrianthi Micevski ass. nova vo vegetacijata na brdskite pasišta vo Makedonija. God. zb. PMF-Biol., Skopje, 24(1971), pp.59-65.
[12] L. Mucina, H. Bültmann, K. Dierßen, J-P. Theurillat, T. Raus, A. Čarni, K. Šumberová, W. Willner, J. Dengler, (...) \& L. Tichý, In print. Vegetation of Europe: Hierarchical floristic classification system of plant, bryophyte, lichen, and algal communities. Applied Vegetation Science, 2016, in print.

[13] S. Rivas-Martínez, T. Díaz, F. FernándezGonzález, J. Loidi, M. Lousá, \& A. Penas, Syntaxonomical checklist of vascular plant communities of Spain and Portugal to association level. Itinera Geobotánica 14. (2001).

[14] R. Di Pietro, J. P. Theurillat, J. Capelo, F. F. González, M. Terzi, A. Čarni, \& L. Mucina. Nomenclature and syntaxonomic notes on some high-rank syntaxa of the European grassland vegetation LAZAROA 36 (2015), pp. 79-106.

[15] H. Weber, J. Moravec, \& J.-P. Theurillat, International Code of Phytosociological Nomenclature. 3rd edition. Journal of Vegetation Science 11 (2000), pp. 739-768.

[16] N. Randjelović, Scabioso-Trifolion dalmatici H-ić \& Randj. nova sveza reda Astragalo-Potentilletalia Micevski, Glasnik Prirodnjačkog muzeja, Ser. B, 28 (1973), pp. 23-27.

[17] N. Randjelović \& Ružič, M. Pašnjačka serpentinska vegetacija jugoistočne Srbije (asociacija Festuco-Plantaginetum serpentini Ranđ. et Ružić 1982). Glasnik Prirodnjačkog muzeja, Serija B, 38 (1983), pp. 55-61.

[18] M. Konstantinou, Phytosociological studies of the vegetation on metalliferous soils, in northern Greece, Institute of Systematic Botany and Phytogeography, Dept. Botany, Aristotle University, Thessaloniki, 1992.

[19] I. Horvat, Istraživanje vegetacije planina Vardarske banovine. I. Ljet. Jug. Akad. Zn. Umj. Zagreb 47 (1935), pp.142-160.

[20] I. Horvat, Istraživanje vegetacije planina Vardarske banovine. II. Ljet. Jug. Akad. Zn. Umj. Zagreb 48 (1936), pp. 211-227.

[21] I. Horvat, Istraživanje vegetacije planina Vardarske banovine. III. Ljet. Jug. Akad. Zn. Umj. Zagreb 49 (1937), pp. 175-180.

[22] I. Horvat, Istraživanje vegetacije planina Vardarske banovine. IV. Ljet. Jug. Akad. Zn. Umj. Zagreb 50 (1938), pp. 136-142.

[23] I. Horvat, Istraživanje vegetacije planina Vardarske banovine. V. Ljet. Jug. Akad. Zn. Umj. Zagreb 50 (1939), pp. 145-148. 
[24] I. Horvat, Planinska vegetacija Makedonije u svijetu suvremenih istraživanja. Acta Musei Macedon. Scient. Nat. 6 (1960), pp. 163-203.

[25] I. Horvat, V. Glavač and H. Ellenberg, Vegetation of Sudosteuropas. Geobotanica Selecta, IV. Gustav Fischer Verlag, Stuttgart, 1974.

[26] B. Trpkov, R. Rizovski \& V. Maletić, Programa za zaštita na divečot vo nacionalniot park "Galičica" period 1993-2002, RO "Nacionalni parkovi i lovišta", Skopje, 1993.

[27] T. Andonovski, M. Stojanović, M. Georgiev, D. Kolčakovski, S. Stankovski, M. Gaševski, D. Vasilevski, M. Panov, C. Gramatnikovski, Lj, Milenkovski. \& A.Stojmilov: The report for the project Pelister and Galicica, natural and sociographic research. Institute of Geography, Faculty of Science, UKIM - Skopje, 1990.

[28] V. Matevski, Raznovidnost i poteklo na florata na Republika Makedonija. Pristapni predavanja, prilozi i bibliografija na novite členovi na Makedonskata akademija na naukite i umetnostite. ["Diversity and origin of the flora of the Republic of Macedonia. Accession lectures, contributions and bibliography of the new members of the Macedonian Academy of Sciences and Arts"], MANU, Skopje, 2013, pp. 125-186.

[29] J.Braun-Blanquet, Pflanzensoziologie: Grundzuge der Vegetationskunde. 3. neu bearb. Aufl. Springer-Verlag, Wien, 1964, 866 pp.

[30] T. G. Tutin, V. H. Heywood, N. A. Burges, D. M. Moore, D. H. Valentine, S. M. Walters \& D. A. Webb, [Eds.]: Flora Europaea, Volume 2: Rosaceae to Umbelliferae. Cambridge: Cambridge University Press, 1968.

[31] T. G. Tutin, V. H. Heywood, D. M. Burges, D. H. Valentine, S. M. Walters \& D. A. Webb, [Eds.]: Flora Europaea, Volume 3: Diapensiaceae to Myoporaceae. Cambridge, Cambridge University Press, 1972.

[32] T. G. Tutin, V. H .Heywood, D. M. Burges, D. H. Valentine, S. M. Walters \& D. A. Webb, [Eds.]: Flora Europaea, Volume 4: Plantaginaceae to Compositae (and Rubiaceae). Cambridge, Cambridge University Press, 1976.

[33] T. G. Tutin, V. H. Heywood, D. M. Burges, D. H. Valentine, S. M. Walters \& D. A. Webb, [Eds.]: Flora Europaea, Volume 5: Alismataceae to Orchidaceae (Monocotyledones), Cambridge, Cambridge University Press, 1980.

[34] T. G. Tutin, D. M. Burges, A. O. Chater, J. R. Edmonson, V. H. Heywood, D. M. Moore, D. H. Valentine, S. M. Walters \& D. A. Webb, [Eds.]: Flora Europaea, Volume 1: Psilotaceae to Platanaceae. 2nd ed. Cambridge, Cambridge University Press, 1993.

[35] A. Hayek, Prodromus Florae peninsulae Balcanicae, 1. Repert. Spec. Nov. Regni Veg. 30 (1), Berlin, 1924-1927, pp. 1-1193.
[36] A. Hayek, Prodromus Florae peninsulae Balcanicae, 2. Repert. Spec. Nov. Regni Veg., Beih., 30 (2), Berlin, 1928-1931, pp. 1-1152.

[37] A. Hayek, Prodromus Florae peninsulae Balcanicae, 3. Repert. Spec. Nov. Regni Veg., Beih., 30 (3), Berlin, 1932-1933, pp. 1-472.

[38] K. Micevski, Flora na Republika Makedonija. MANU, Skopje, 1 (1), 1985, pp.1-153.

[39] K. Micevski, Flora na Republika Makedonija. MANU, Skopje, 1 (2), 1993, pp. 153-391.

[40] K. Micevski, Flora na Republika Makedonija. MANU, Skopje, 1 (3), 1995, pp. 401-772.

[41] K. Micevski, Flora na Republika Makedonija. MANU, Skopje, 1 (4), 1998, pp. 781-1113.

[42] K. Micevski, Flora na Republika Makedonija. MANU, Skopje, 1 (5), 2001, pp. 1121-1430.

[43] K. Micevski, Flora na Republika Makedonija. MANU, Skopje, 1 (6): 2005, pp. 1433-1715.

[44] V. Matevski, Flora na Republika Makedonija, MANU, Skopje, 2/1, 2010, pp. 1-190

[45] D. Jordanov, Flora na Narodna Republika Bălgarija, Sofija, (ed.) 1-6, 1963-1976.

[46] D. Jordanov, \& B. Kuzmanov, Flora na Narodna Republika Bălgarija, Sofija, (eds.) 7, 1979.

[47] V. Velčev, S. Kožuharov \& B. Kuzmanov, Flora na Republika Bălgarija, Sofija, (eds.) 9, 1989.

[48] M. Josifović, Flora SR Srbije. Srpska akademija nauka i umetnosti, Beograd. I-IX, 1970-1977.

[49] S. M. Hennekens \& J. H. J. Schaminée, TURBOVEG, comprehensive data base management system for vegetation data. Journal of Vegetation Science 12, (2001), pp. 589-591.

[50] L. Tichý, JUICE, software for vegetation classification. J. Veg. Sci. 13, (2002), pp. 451-453.

[51] B. McCune \& M. J. Mefford, PC-ORD Multivariate analysis of ecological data, version 5. MjM Software Design, Glenede Beach, Oregon, USA, 1999.

[52] L. Tichý, M. Chytrý, M. Hájek, S. S. Talbot \& Z. Botta-Dukát, OptimClass using species to clusterfidelity to determine the optimal partition in classification of ecological communities. J. Veg. Sci, 21 (2010), pp. 287-299.

[53] M. Chytrý, L. Tichý, J. Holt \& J. Botta-Dukát, Determination of diagnostic species with statistical fidelity measures. J. Veg. Sci., 13 (2002), pp. 7990 .

[54] C. Raunkiaer, The life forms of plants and statistical plant geography. Oxford, Charendon Press, 1934.

[55] M. Gajić, Pregled vrsta flore S. R. Srbije sa biljnogeografskim oznakama. Glasnik Šumarskog Fakulteta, Serie A "Šumarstvo", Beograd, 54, (1980), pp. 111-141. 
[56] S. Pignatti, Valori di Bioindicazione delle Piante Vascolaridella Flora d'Italia. Braun-Blanquetia, 39 (2005), pp. 1-97.

[57] V. Matevski, R. Lozanovski, M. Kostadinovski, Silene-Thymetum ciliatopubescentis ass. nova in the vegetation on highland pastures in the Repub- lic of Macedonia. Collection of Papers Devoted to Academician Kiril Micevski. MANU, Skopje, 2007.

[58] K. Micevski, Prilog za zapoznavanje na florata na Makedonija, I. God. zb. Filozof. fak.-Prirod. matem. oddel, 9 (1956), pp. 99-118.

\section{БРДСКИ ПАСИШТА НА НАЦИОНАЛНИОТ ПАРК ГАЛИЧИЦА (ЈЗ МАКЕДОНИЈА)}

\section{Рената Ќуштеревска}

Институт за биологија, Природно-математички факултет, Универзитет „Св. Кирил и Методиј“, Скопје, Република Македонија

Во трудот се презентирани брдските пасишта (Festuco-Brometea) во Националниот парк „Галичица“. Истражувањата на кои се темели овој труд беа спроведени во периодот од 2009-2010 на повеќе локалитети, на карбонатна подлога, од охридската и преспанската страна. Регистрираната заедница од овој тип е подредена кон редот Astragalo-Potentilletalia Мицевски [1] и сојузот Saturejo-Thymion Мицевски [2]. Од флористичкиот состав и деталните фитоценолошки анализи на истражуваната вегетација беше заклучено дека класата Festuco-Brometea е претставена со асоцијацијата Siderito montanae-Trifolietum dalmaticae ass. nova subass. erodietosum guicciardii subass. nova.

Клучни зборови: вегетација; брдски пасишта; Галичица 
